\title{
Influence Applied Potential on the Formation of Self-Organized ZnO Nanorod Film and Its Photoelectrochemical Response
}

\author{
Nur Azimah Abd Samad, Chin Wei Lai, and Sharifah Bee Abd Hamid \\ Nanotechnology \& Catalysis Research Centre (NANOCAT), Institute of Postgraduate Studies (IPS), University of Malaya, \\ 3rd Floor, Block A, 50603 Kuala Lumpur, Malaysia \\ Correspondence should be addressed to Chin Wei Lai; cwlai@um.edu.my
}

Received 11 March 2016; Revised 17 April 2016; Accepted 27 April 2016

Academic Editor: Ahmad Umar

Copyright (C) 2016 Nur Azimah Abd Samad et al. This is an open access article distributed under the Creative Commons Attribution License, which permits unrestricted use, distribution, and reproduction in any medium, provided the original work is properly cited.

The present paper reports on the facile formation of $\mathrm{ZnO}$ nanorod photocatalyst electrodeposited on $\mathrm{Zn}$ foil in the production of hydrogen gas via water photoelectrolysis. Based on the results, $\mathrm{ZnO}$ nanorod films were successfully grown via electrochemical deposition in an optimum electrolyte set of $0.5 \mathrm{mM}$ zinc chloride and $0.1 \mathrm{M}$ potassium chloride at $\mathrm{pH}$ level of 5-6 and electrochemical deposition temperature of around $70^{\circ} \mathrm{C}$. The study was also conducted at a very low stirring rate with different applied potentials. Applied potential was one of the crucial aspects in the formation of self-organized $\mathrm{ZnO}$ nanorod film via control of the field-assisted dissolution and field-assisted deposition rates during the electrochemical deposition process. Interestingly, low applied potentials of $1 \mathrm{~V}$ during electrochemical deposition produced a high aspect ratio and density of self-organized $\mathrm{ZnO}$ nanorod distribution on the $\mathrm{Zn}$ substrate with an average diameter and length of $\sim 37.9 \mathrm{~nm}$ and $\sim 249.5 \mathrm{~nm}$, respectively. Therefore, it exhibited a high photocurrent density that reached $17.8 \mathrm{~mA} / \mathrm{cm}^{2}$ under ultraviolet illumination and $12.94 \mathrm{~mA} / \mathrm{cm}^{2}$ under visible illumination. This behaviour was attributed to the faster transport of photogenerated electron/hole pairs in the nanorod's one-dimensional wall surface, which prevented backward reactions and further reduced the number of recombination centres.

\section{Introduction}

Based on records dating back to 1880 by NASA, Earth's surface temperature was the warmest in 2015 [1]. The outgoing heat absorbed by greenhouse gases, like carbon dioxide, methane, and nitrous oxide, was reemitted in all directions, resulting in the increase of Earth's surface temperature [2]. The emission of greenhouse gases was mostly caused by the combustion of fossil fuels. Therefore, many parties have tried to create alternative energy substitutes to the current energy sources around the world. One of the alternatives is hydrogen gas. In the 21st century, the transition of fuel from liquid to gas phase, commonly known as the hydrogen economy, for future sustainability of fuel and hydrogen-based economies will have an impact on all sectors in the long term.

In this research, $\mathrm{ZnO}$ was chosen as the photocatalyst for water splitting applications in hydrogen gas production due to its essential cost-benefit to the industry. $\mathrm{ZnO}$ nanorods have high transparency in the visible range and high light trapping characteristics which is very important for PEC water splitting applications [3]. Additionally, the radiation hardness can be applied at high altitudes or even in space with its transparent and conductive properties [4-7]. $\mathrm{ZnO}$ has a large number of nanostructures in one-dimensional (1D) form: combs [8], wires [9-11], belts [12, 13], tubes [14-16], spring and ring [17], ribbon, helixes, needle [18], and nanorod [19-21]; two-dimensional (2D) form: nanopellets and nanosheets $[22,23]$; and three-dimensional (3D) form: dendrites, flower, dandelion, coniferous structure, and snowflakes [11, 24-29]. In this research, we focused on the formation of $\mathrm{ZnO}$ nanorods and studied their morphology, phase, and photochemical responses.

Another convincing motivation arose from the benefits of a one-dimensional (1D) $\mathrm{ZnO}$ nanostructure. Since the mobility of electrons was crucial for the formation of hydrogen gas, a 1D nanostructure was selected for this research due to its anisotropic mobility of electrons. The electron mobility increased with the decrease of density for electrons available to scatter. This electron mobility behaviour was attributed to the faster transport of photogenerated electron/hole pairs 
TABLE 1: The revolution of $\mathrm{ZnO}$ nanorod formation.

\begin{tabular}{|c|c|c|c|}
\hline Researchers & Synthesis method & Research findings & References \\
\hline Azam and Babkair & Low temperature wet chemical method & $\begin{array}{l}\text { ZnO nanorod with diameter } \sim 80-90 \mathrm{~nm} \text { and } \\
\text { length } \sim 350-400 \mathrm{~nm} \text {. }\end{array}$ & {$[33]$} \\
\hline Abbasi et al. & Hydrothermal growth method & $\begin{array}{l}\text { ZnO nanorod with diameter } \sim 150 \mathrm{~nm} \text { and length } \\
\sim 4 \mu \mathrm{m} \text { on silicon substrate. }\end{array}$ & {$[34]$} \\
\hline Alvi et al. & $\begin{array}{l}\text { Low temperature aqueous chemical } \\
\text { growth (ACG) method }\end{array}$ & $\begin{array}{l}\text { Nanowalls, nanorod and nanotubes (diameter } \\
\sim 160 \mathrm{~nm} \text {, length } \sim 1.2 \mu \mathrm{m} \text { ), and nanoflowers. } \\
\text { Different precursor and supporting electrolyte } \\
\text { produced different nanorod. Pretreated p-GaN } \\
\text { substrate. }\end{array}$ & {$[35]$} \\
\hline Chen et al. & $\begin{array}{l}\text { Metalorganic chemical vapor deposition } \\
\text { (MOCVD) }\end{array}$ & $\begin{array}{l}\mathrm{ZnO} \text { nanorod with diameter } \sim 100 \mathrm{~nm} \text { on sapphire } \\
\text { substrate. }\end{array}$ & {$[36]$} \\
\hline Badre et al. & Electrochemical deposition method & $\begin{array}{l}\mathrm{ZnO} \text { nanorod with diameter } \sim 180 \mathrm{~nm} \text { and length } \\
\sim 1.2 \mu \mathrm{m} \text { on } \mathrm{F} \text {-doped } \mathrm{SnO}_{2} \text {-coated glass substrate. }\end{array}$ & {$[37]$} \\
\hline
\end{tabular}

in the nanorod's one-dimensional wall surface, which prevented backward reactions and further reduced the number of recombination centres. Many methods were studied by past researchers to form $\mathrm{ZnO}$ nanorods (Table 1). However, electrochemical deposition promised the best advantages with benefits like being significantly cost-effective, environmentally friendly, easy to implement, uniform in deposition of materials, reliable, and controllable and having low-energy consumption [30-32].

\section{Materials and Methods}

2.1. Synthesis of $\mathrm{ZnO}$ Nanorod. For the preparation of $\mathrm{ZnO}$ nanorods, zinc $(\mathrm{Zn})$ foil (thickness $0.25 \mathrm{~mm}, 99.9 \%$ trace metals basis, Sigma-Aldrich) was dipped in an electrolyte bath composed of $50 \mathrm{~mL}$ of $0.5 \mathrm{mM}$ zinc chloride $\left(\mathrm{ZnCl}_{2}\right)$ and $50 \mathrm{~mL}$ of $0.1 \mathrm{M}$ potassium chloride $(\mathrm{KCl})$ at $1.0-3.0 \mathrm{~V}$ and under a temperature of $70^{\circ} \mathrm{C}$. From our literature studies, a voltage of $1.0 \mathrm{~V}$ and temperature of $70^{\circ} \mathrm{C}$ were selected because the polycrystalline structure of $\mathrm{ZnO}$ would start to evolve at this potential difference and temperature with obvious and randomly oriented grains. The as-prepared electrolyte $\mathrm{pH}$ was about 5-6 and was measured with a Mettler Toledo InLab Expert Pro pH meter. The electrochemical deposition process was conducted with a twoelectrode configuration system, as shown in Figure 1. The platinumelectrode served as the anode while $\mathrm{Zn}$ foil served as the cathode. This closed system was then connected to a DC power supply. After the electrochemical deposition, the nanodeposits were then thoroughly rinsed with EMSURE ACS, ISO, Reag. Ph Eur Acetone for analysis and dried at atmosphere. The deposited $\mathrm{ZnO}$ nanostructured films were then annealed at $350^{\circ} \mathrm{C}$ for 3 hours.

2.2. Characterizations of $\mathrm{ZnO}$ Nanorod. The photoluminescence spectra, crystallinity, and phase transition of the samples were analysed with a Renishaw In Via Raman microscope and the result was supported with the result of Xray dispersive (XRD) Bruker D8 Advance that was equipped with EVA Diffract software (Germany) with $\mathrm{Cu} \mathrm{K}$ radiation

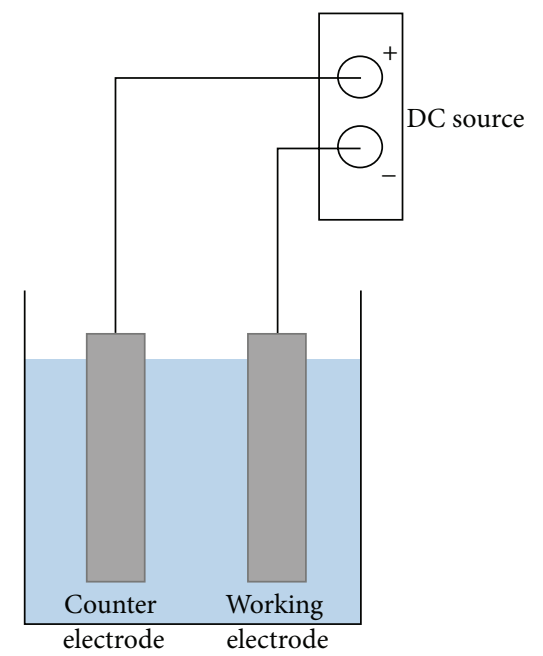

FIGURE 1: Schematic diagram of electrochemical deposition process.

and wavelength of $\lambda=1.5418 \AA$. Meanwhile, the surface and cross-sectional morphologies of the samples were viewed through JEOL JSM-7600F Field Emission Scanning Electron Microscopy (FESEM) and the elemental analysis of the $\mathrm{ZnO}$ nanorod films was determined with a Hitachi Energy Dispersive X-ray (EDX) spectroscopy analysis. To study the photocurrent density of the samples, a three-electrode PEC cell with $\mathrm{ZnO}$ nanorod films as the anode, a platinum rod as the cathode, and a saturated calomel electrode (SCE) as the reference electrode was used in a quartz cell filled with $1 \mathrm{M}$ sodium hydroxide $(\mathrm{NaOH})$ containing $1 \mathrm{v} \%$ of ethylene glycol. A Newport model 74010 light source was focused on the immersed portion of the photoelectrode to stimulate ultraviolet and visible illumination. All of the three electrodes were connected to the potentiostat (Metrohm Autolab PGSTAT204) and the corresponding current-applied potential value was measured. The photocurrent density was measured with Metrohm Autolab PGSTAT204 with a procedure linear sweep voltammetry potentiostatic applied potential of -1 to $1 \mathrm{~V}$. 


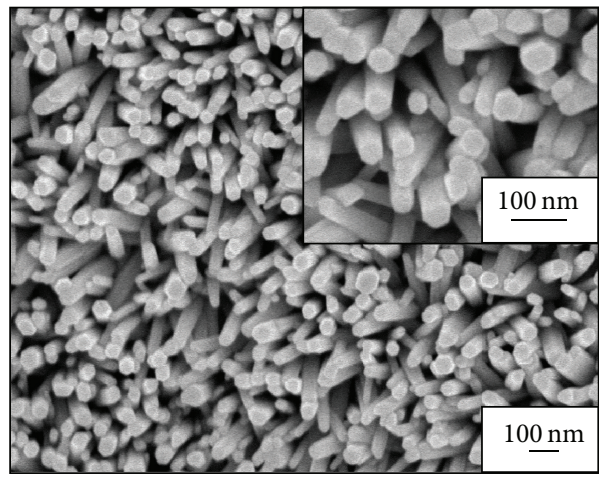

(a)

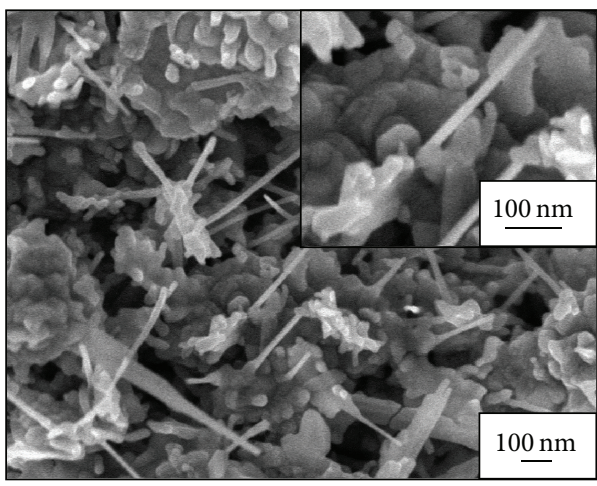

(c)

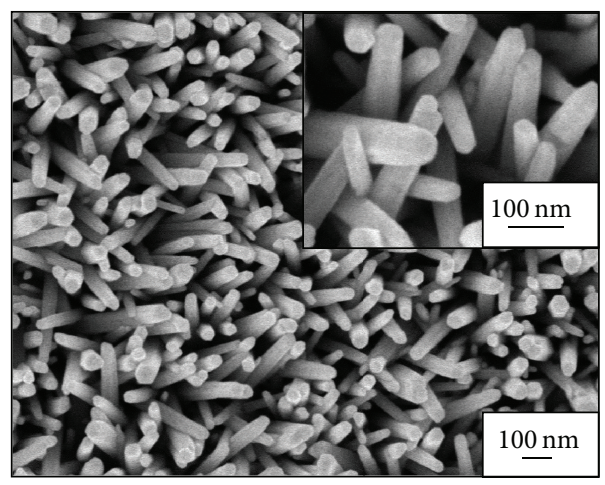

(b)

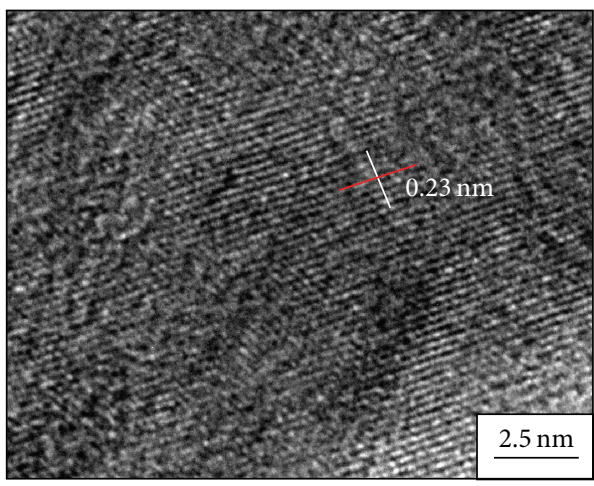

(d)

FIGURE 2: FESEM images: (a) $1 \mathrm{~V}$ of electrochemical deposition applied potential; (b) $2 \mathrm{~V}$ of electrochemical deposition applied potential; (c) $3 \mathrm{~V}$ of electrochemical deposition applied potential. HRTEM image: (d) $1 \mathrm{~V}$ of electrochemical deposition applied potential.

\section{Results and Discussion}

3.1. Morphological Structure of $\mathrm{ZnO}$ Nanorod. The appearance of deposited zinc oxide on $\mathrm{Zn}$ foil can be said to be dependent on the applied potential during electrodeposition with an optimum set of other variables like $0.5 \mathrm{mM}$ zinc chloride and $0.1 \mathrm{M}$ potassium chloride electrolyte, $\mathrm{pH}$ level of $\sim 5-6$, electrochemical deposition temperature $\sim 70^{\circ} \mathrm{C}$, and a very low stirring rate. Dimensions and uniformity of the morphology of $\mathrm{ZnO}$ were a function of the applied potential in the $\mathrm{ZnCl}_{2}$ and $\mathrm{KCl}$ electrolyte. For samples deposited under $1 \mathrm{~V}$ (Figure 2(a)), nanorods with an average diameter of $37.9 \mathrm{~nm}$ and average length of $249.5 \mathrm{~nm}$ were produced with near-perfect $c$-direction. When the applied potential was increased to $2 \mathrm{~V}$, the diameter of the nanorods became slightly larger with an average of $61.6 \mathrm{~nm}$ but with shorter average lengths of $211.2 \mathrm{~nm}$ (Figure 2(b)). In this manner, increases in applied potential produced reductions in lengths as higher precursor dissolution occurred at higher potentials and the $\mathrm{Zn}^{2+}$ concentrations were higher in the [0001] direction. Hence, the unit growing in the [1000] direction was preferred and therefore increased in diameter [25, 38]. However, upon achieving steady state, the propagation or crystal growth at direction [1000] would be terminated and the nucleation of new crystals started in the direction of [0001] again. The process would repeat until the applied potential stopped. However, any further increases in applied potential to $3 \mathrm{~V}$ would cause irregular features on the surface of the $\mathrm{Zn}$ foil and create a dense $\mathrm{ZnO}$ structure instead of ordered nanopores that were previously observed. It can be concluded that higher applied potentials produced negative effects on the self-ordering of the deposited zinc oxide, whereby the nanorod structure disappeared and the deposited zinc oxide would be composed of irregular and dense structures with thicknesses of $\sim 2.78 \mu \mathrm{m}$, as shown in Figure 2(c). Therefore, a minimum potential of $1 \mathrm{~V}$ was found to be optimum for the formation of self-organized $\mathrm{ZnO}$ nanorods with lengths approaching $249.5 \mathrm{~nm}$ in 60 minutes. On the other hand, the lattice fringes of $1 \mathrm{~V}$ samples measured $0.23 \mathrm{~nm}$ and indicated (101) $\mathrm{ZnO}$ wurtzite (Figure 2(d)).

The final morphology of $\mathrm{ZnO}$ nanorods was the competition of field-assisted dissolution and field-assisted deposition of $\mathrm{ZnO}$. By applying higher potentials, strong electric fields helped to accelerate the three-step formation of $\mathrm{ZnO}$ nanorods. The driving force of externally applied potential led to the dissolution of $\mathrm{ZnCl}_{2}, \mathrm{KCl}$, and water (fieldassisted dissolution). Equation (1) shows the dissolution of $\mathrm{KCl}+\mathrm{ZnCl}_{2}+\mathrm{H}_{2} \mathrm{O}$. Equation (2) shows the formation of zinc hydroxide $\left(\mathrm{Zn}(\mathrm{OH})_{2}\right)$. Equation (3) shows the reaction $\mathrm{Zn}(\mathrm{OH})_{2}+\mathrm{HCl}+\mathrm{KOH} \rightarrow \mathrm{ZnO}+\mathrm{H}_{2} \mathrm{O}+\mathrm{KCl}$. When the ionic species arrived at the cathode under the influence of applied potential, there was a difference between the actual concentration and solubility concentration (supersaturation) due to the increased local $\mathrm{pH}$ of $\mathrm{KOH}$ at the cathode which 
TABLE 2: Average compositional ratios for $1 \mathrm{~V}, 2 \mathrm{~V}$, and $3 \mathrm{~V}$ applied potential from EDX spectroscopy.

\begin{tabular}{lccc}
\hline \multirow{2}{*}{ Element } & \multicolumn{3}{c}{ Atomic percentage (\%) } \\
& $1 \mathrm{~V}$ & $2 \mathrm{~V}$ & $3 \mathrm{~V}$ \\
\hline $\mathrm{Zn}$ & 50.3 & 51.7 & 55.9 \\
$\mathrm{O}$ & 49.7 & 48.3 & 44.1 \\
\hline
\end{tabular}

produced very high supersaturation. Therefore, in (3), the nucleation of $\mathrm{ZnO}$ was started (field-assisted deposition) by the dehydration process of $\mathrm{Zn}(\mathrm{OH})_{2}$ to $\mathrm{ZnO}[4,25]$. EDX spectroscopy showed averages of 50.3 at $\% \mathrm{Zn}$ and 49.7 at $\% \mathrm{O}$, 51.7 at $\% \mathrm{Zn}$ and 48.3 at $\% \mathrm{O}$, and 55.9 at $\% \mathrm{Zn}$ and 44.1 at $\% \mathrm{O}$ for the respective $1 \mathrm{~V}, 2 \mathrm{~V}$, and $3 \mathrm{~V}$ applied potential samples (Table 2). Below are the equations for the formation of $\mathrm{ZnO}$ nanorods and a summary of the diameter, length, and aspect ratios of $1 \mathrm{~V}, 2 \mathrm{~V}$, and $3 \mathrm{~V}$ as shown in Table 3 .

Dissolution of $\mathrm{KCl}+\mathrm{ZnCl}_{2}+\mathrm{H}_{2} \mathrm{O}$ occurs as follows:

$$
\begin{gathered}
\mathrm{KCl} \longrightarrow \mathrm{K}^{+}(\mathrm{aq})+\mathrm{Cl}^{-}(\mathrm{aq}) \\
\mathrm{ZnCl}_{2} \longrightarrow \mathrm{Zn}^{2+}(\mathrm{aq})+2 \mathrm{Cl}^{-}(\mathrm{aq}) \\
2 \mathrm{H}_{2} \mathrm{O} \longrightarrow \mathrm{H}_{2} \uparrow+2 \mathrm{OH}^{-}(\mathrm{aq})
\end{gathered}
$$

Formation of zinc hydroxide $\left(\mathrm{Zn}(\mathrm{OH})_{2}\right), \mathrm{KOH}$, and $\mathrm{KCl}$ occurs as follows:

$$
\mathrm{K}^{+}(\mathrm{aq})+\mathrm{OH}^{-}(\mathrm{aq}) \longrightarrow \mathrm{KOH}
$$

(increase in local $\mathrm{pH}$ at the cathode)

$$
\begin{aligned}
& \mathrm{Zn}^{2+}(\mathrm{aq})+2 \mathrm{OH}^{-}(\mathrm{aq}) \longrightarrow \mathrm{Zn}(\mathrm{OH})_{2} \\
& \mathrm{H}_{2} \uparrow+2 \mathrm{Cl}^{-} \longrightarrow 2 \mathrm{HCl}
\end{aligned}
$$

Formation of zinc oxide ( $\mathrm{ZnO})$ occurs as follows:

$$
\mathrm{Zn}(\mathrm{OH})_{2} \longrightarrow \mathrm{ZnO}+\mathrm{H}_{2} \mathrm{O}
$$

(dehydration process)

$$
\mathrm{HCl}+\mathrm{KOH} \longrightarrow \mathrm{H}_{2} \mathrm{O}+\mathrm{KCl}
$$

3.2. Structural Analysis for $\mathrm{ZnO}$ Nanorod. In this study, Raman analysis was used to determine and understand the structural changes of $\mathrm{ZnO}$ with different applied potential. Raman inelastic scattering is shown at peak $E_{2}$ (high) mode at $438 \mathrm{~cm}^{-1}$ and indicated that the $\mathrm{ZnO}$ nanostructures' thin film had crystal wurtzite structures with the highest intensity at $1 \mathrm{~V}$ (796.5 counts) (Figure 3(a)) as compared to $2 \mathrm{~V}$ (468.4 counts) and $3 \mathrm{~V}$ (459.7 counts) (Figures 3(b) and $3(\mathrm{c})$ ). However, these thin films in both samples were still weak in pure stoichiometric $\mathrm{ZnO}$ due to the dominance of $E_{1}$ (LO) and $A_{1}$ (LO) mode $\left(570-585 \mathrm{~cm}^{-1}\right)$ as compared to $E_{2}$ (high) mode at $438 \mathrm{~cm}^{-1}$ and this situation normally occurs in $\mathrm{Zn}$ rich $\mathrm{ZnO}$ thin films. This can also be due to deficiency in oxygen atoms represented by these two

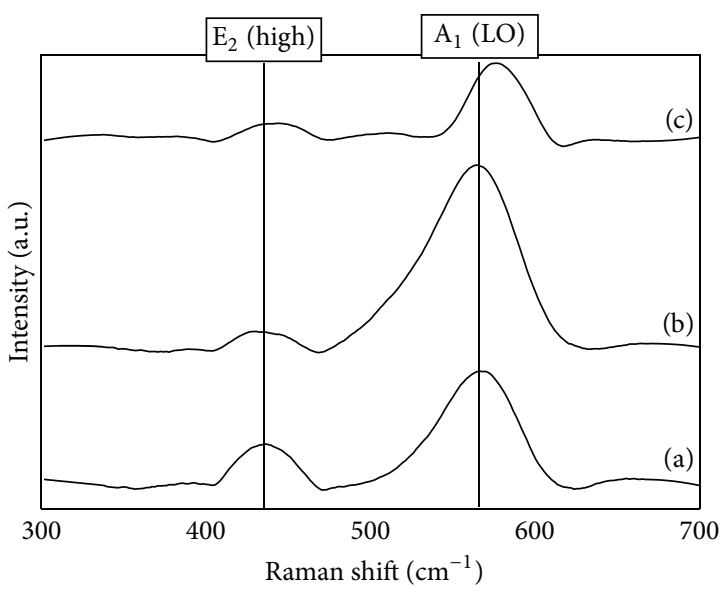

FIgURE 3: Raman spectra for (a) $1 \mathrm{~V}$, (b) $2 \mathrm{~V}$, and (c) $3 \mathrm{~V}$ (excitation: $\lambda=514 \mathrm{~nm})$.

modes $\left(E_{1}(\mathrm{LO})\right.$ and $A_{1}(\mathrm{LO})$ mode $\left.\left(570-585 \mathrm{~cm}^{-1}\right)\right)$ with the existence of $\mathrm{Zn}$ elements from the $\mathrm{Zn}$ substrate [39, 40]. Besides this, the shift in the peaks occurred due to the differences in structure. For the $1 \mathrm{~V}$ and $2 \mathrm{~V}$ sample, it has appeared in the $\mathrm{ZnO}$ nanorods and the asymmetric $\mathrm{LO}$ phonon peaks were observed at $571 \mathrm{~cm}^{-1}$. Meanwhile, the $3 \mathrm{~V}$ samples had dense structures ( $\mathrm{ZnO}$ bulk crystal); therefore, the frequency of the $\mathrm{LO}$ phonon was located at $574 \mathrm{~cm}^{-1}$ [41]. In addition to this, many researchers found that the shift occurred at at least $3 \mathrm{~cm}^{-1}$ [42-44]. The shift of the peak occurred due to the defects or impurities in the nanocrystals, optical phonon confinement, laser irradiation heating, and the tensile strain effect $[41,45]$. Furthermore, the intensity of the peaks was reduced by increasing the applied potential. This occurred due to the quality of the materials which in turn also affected the Raman intensity where higher crystalline quality exhibited higher intensity. Increases in grain size also produced a substantial reduction in asymmetry and intensity of the peaks [46].

The XRD pattern supported the Raman scattering as it showed that the $\mathrm{ZnO}$ nanorods were in wurtzite phase which belonged to reference code ICDD 00-036-1451 with a hexagonal crystal system. The plane attributes for this $\mathrm{ZnO}$ were $31.7^{\circ}(100), 34.4^{\circ}(002), 36.3^{\circ}(101), 47.5^{\circ}$ (102), $56.6^{\circ}$ (110), $62.9^{\circ}$ (103), and $67.9^{\circ}$ (112) (Figure 4). The wurtzite $\mathrm{ZnO}$ crystallographic lattice parameters were $a=3.25 \AA, b=$ $3.25 \AA$, and $c=5.21 \AA$, which confirmed that the number of alternating planes consisted of $\mathrm{O}^{2-}$ and $\mathrm{Zn}^{2+}$ that were stacked in tetrahedral structures along the $c$-axis [47]. 43.2 (101) and $76.9^{\circ}$ (004) showed the apparent existence of $\mathrm{Zn}$ elements which also reinforced the Raman scattering results (Figure 4).

3.3. Photoluminescence Behaviour. The photoluminescence study for $\mathrm{ZnO}$ nanorods was mainly related to some defects, for instance, the zinc vacancies, zinc interstitial, oxygen vacancies, oxygen interstitial, and oxygen antisites. The 350$450 \mathrm{~nm}$ region determined the exciton recombination process and is triggered by the recombination of free excitons, 
TABLE 3: Average values for length, diameter, and aspect ratio for different applied potentials.

\begin{tabular}{lcccc}
\hline Potential $(\mathrm{V})$ & Surface morphology & Length $(\AA)$ & Diameter $(\AA)$ & Average aspect ratio \\
\hline 1 & Nanorod & $2495 \pm 103$ & $379 \pm 12$ & 6.58 \\
2 & Nanorod & $2112 \pm 98$ & $616 \pm 16$ & 3.43 \\
3 & Dense structure & $27890 \pm 225$ & - & - \\
\hline
\end{tabular}

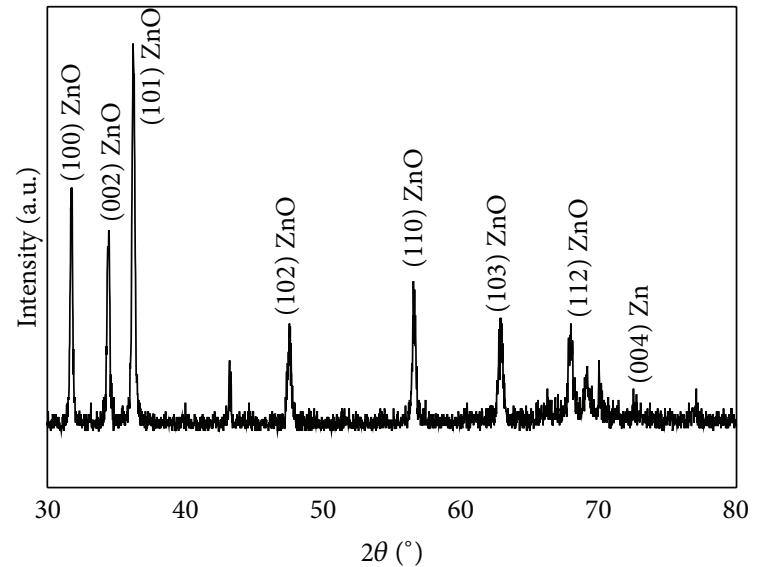

FIgURE 4: The XRD pattern for $\mathrm{ZnO}$ nanorod for $1 \mathrm{~V}$ applied potential.

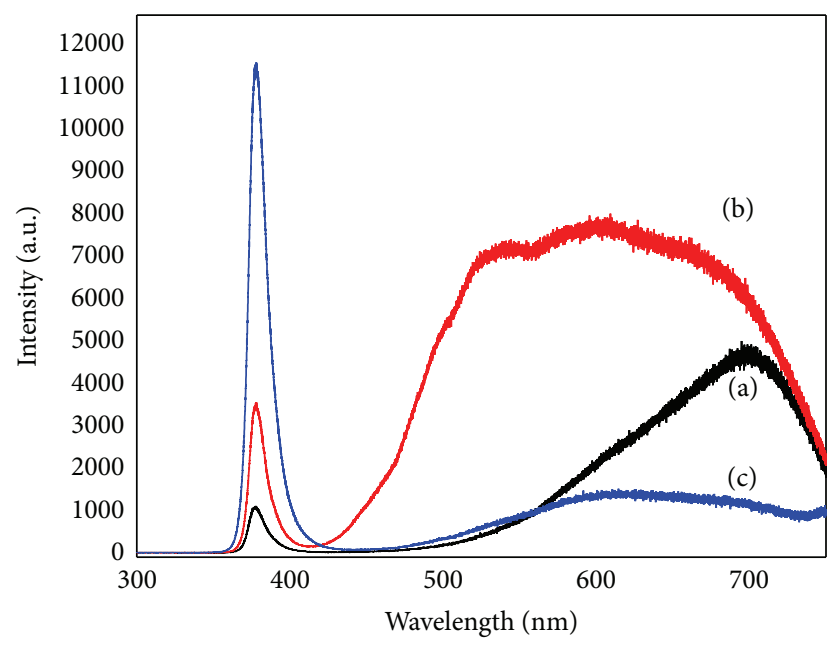

FIGURE 5: PL spectra for sample: (a) $1 \mathrm{~V}$, (b) $2 \mathrm{~V}$, and (c) $3 \mathrm{~V}$ (excitation: $\lambda=514 \mathrm{~nm}$ ).

which points to the good crystallinity of the $\mathrm{ZnO}$ nanorods $[48,49] .1 \mathrm{~V}$ sample showed the greatest $\mathrm{ZnO}$ nanorod crystallinity arrangement since it had the least emissions at the $50-450 \mathrm{~nm}$ region (UV region) but small emissions at the $600-700 \mathrm{~nm}$ region (orange-red region) indicated small intrinsic defects which was attributed to the presence of small excess oxygen such as oxygen interstitial [50]. This result is supported by EDX which shows a high atomic percentage of oxygen at $49.7 \%$ (Figure 5(a)). On the other hand, the sample $2 \mathrm{~V}$ showed combinations of more than one defect. Based on the available literature, this could be a combination of an oxygen vacancy and zinc interstitial, $\mathrm{V}_{\mathrm{o}} \mathrm{Zn}_{\mathrm{i}}$ [51]. The origin of green emissions normally came from oxygen based defects [51-54] and a combination of both defects, oxygen vacancy and zinc interstitial defect, produced broad green, yellow, and orange region (Figure 5(b)) [51, 55]. EDX proved that \% imbalance occurred in the $2 \mathrm{~V}$ sample; the atomic percentage of oxygen $(48.3$ at\%) was lower than that of zinc (51.7 at\%). Nevertheless, a few researchers proposed that high volumes of $\mathrm{Zn}(\mathrm{OH})_{2}$ could also produce the broad green, yellow, and orange region $[50,56]$. In this case, insufficient annealing was one of the reasons. A second reason would be the rate of field-assisted deposition that was higher compared to the rate of dehydration (formation of $\mathrm{ZnO}$ ). It therefore produced a high volume of $\mathrm{Zn}(\mathrm{OH})_{2}$ on the nanorod surface. This proposed reason would need further investigation for confirmation. The $3 \mathrm{~V}$ sample showed that the superlative performance at the $500-800 \mathrm{~nm}$ region for $\mathrm{ZnO}$ indicated fewer defects but had very high free exciton recombination at the $350-450 \mathrm{~nm}$ region which showed poor crystallinity arrangements of $\mathrm{ZnO}$. The $3 \mathrm{~V}$ sample's results indicated that the dense structure was based on its morphology and was in the bulk $\mathrm{ZnO}$ as per the results of Raman analysis.

3.4. Photoelectrochemical Response. $\mathrm{ZnO}$ with its excellent electronic properties and interfacial stability exhibited great photoelectrochemical response for hydrogen generation. The electrical simulation for water electrolysis (hydrogen generation) was studied by using photoelectrochemical response focusing on the photocurrent density analysis (Figures 6 and 7). Water splitting in excess of $90 \%$ occurred with applied potentials of -1 to $1 \mathrm{~V}$ [57]. This small current was needed to maintain the double-layer (surface charging and redox reaction) electron flow at the electrodes' surface [58]. A lot of literature has reported that the high active surface areas of photocatalysts generally exhibited excellent photocatalytic and photoelectrochemical responses due to the high percentage of produced and exposed atoms and ions on the catalyst surface. Therefore, a high volume of active sites was crucial for catalytic reactions [59]. Furthermore, the increments in rod lengths provided the fastest way for the charges to be transported along the longitudinal direction of a $1 \mathrm{D}$ singlecrystalline nanomaterial $[58,59]$. In addition, it helped ionic species to have higher driving force in order to move through the barrier layer of the $\mathrm{ZnO}$ nanorod tip. The large active area referred to a high average aspect ratio (Table 3 ).

The $1 \mathrm{~V}$ applied potential exhibited the highest photocurrent density, $J_{p}$, for ultraviolet illumination $\left(17.8 \mathrm{~mA} / \mathrm{cm}^{2}\right)$ (Figure 6(a)) and visible illumination $\left(12.94 \mathrm{~mA} / \mathrm{cm}^{2}\right.$ ) (Figure $7(\mathrm{a})$ ) as compared to $2 \mathrm{~V}$ (ultraviolet illumination $J_{p}$ $=11.78 \mathrm{~mA} / \mathrm{cm}^{2}$; visible illumination, $J_{p}=10.78 \mathrm{~mA} / \mathrm{cm}^{2}$ ) 


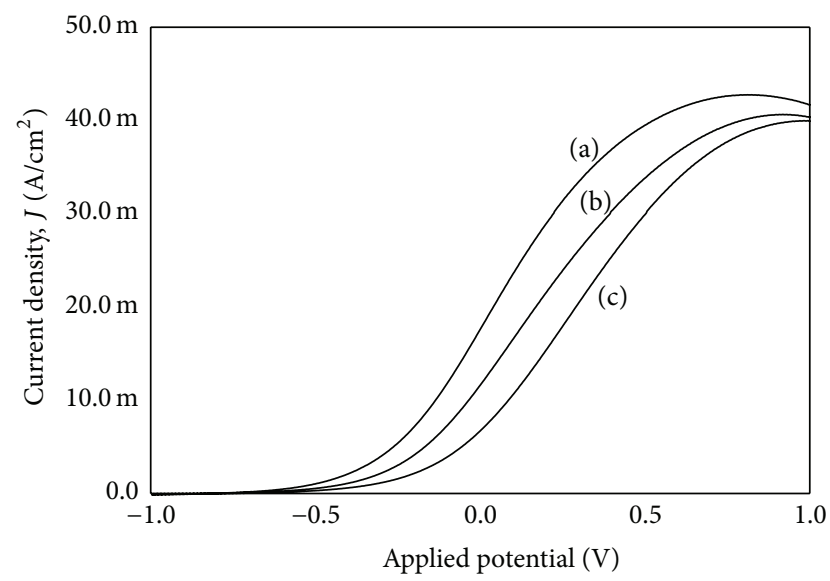

FIGURE 6: Current density-applied potential characteristics for (a) $1 \mathrm{~V}$, (b) $2 \mathrm{~V}$, and (c) $3 \mathrm{~V}$ under ultraviolet illumination.

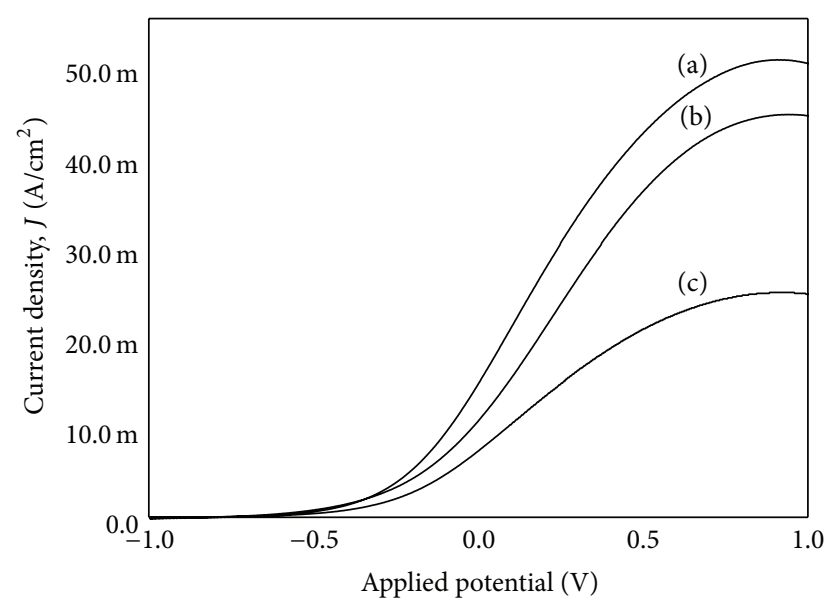

FIGURE 7: Current density-applied potential characteristics for (a) $1 \mathrm{~V}$, (b) $2 \mathrm{~V}$, and (c) $3 \mathrm{~V}$ under visible illumination.

(Figures 6(b) and 7(b)). Based on the above statements, the $1 \mathrm{~V}$ applied potential exhibited the highest photocurrent density results due to it possessing the highest aspect ratio as compared to $2 \mathrm{~V}$ (Table 3 ). Meanwhile, the $3 \mathrm{~V}$ applied potential exhibited an ultraviolet illumination photocurrent density, $J_{p}$, of $6.83 \mathrm{~mA} / \mathrm{cm}^{2}$ and $5.74 \mathrm{~mA} / \mathrm{cm}^{2}$ for visible illumination (Figures 6(c) and $7(\mathrm{c})$ ). The dense porous structures ( $3 \mathrm{~V}$ applied potential) inhibited the charge transfer competence via $\mathrm{ZnO}$ (anode) and this charge transfer competence significantly decreased the collection of current density, $J$, and thus reduced the photocurrent density, $J_{p}$, which represented the photoresponse activity.

\section{Conclusion}

In this paper, it was found that the optimum electrolyte mixture consisted of $0.5 \mathrm{mM}$ zinc chloride and $0.1 \mathrm{M}$ potassium chloride, with $\mathrm{pH}$ value of $\sim 5-6$, electrochemical deposition temperature of $\sim 70^{\circ} \mathrm{C}$, and a very low stirring rate. When this optimum electrolyte mixture was run through an applied potential of $1 \mathrm{~V}$ and other important conditions, $\mathrm{ZnO}$ nanorods were produced with the highest average aspect ratio morphology. These nanorods also had the highest photocurrent density, $J_{p}$, with a value of $17.8 \mathrm{~mA} / \mathrm{cm}^{2}$ under ultraviolet illumination and $12.94 \mathrm{~mA} / \mathrm{cm}^{2}$ under visible illumination. Apart from the phase analysis, the sample $\mathrm{ZnO}$ confirmed it was a wurtzite type of $\mathrm{ZnO}$ with a number of alternating planes consisting of $\mathrm{O}^{2-}$ and $\mathrm{Zn}^{2+}$ and had stacked tetrahedral structures along the $c$-axis. The free exciton recombination for $1 \mathrm{~V}$ was the lowest as compared to $2 \mathrm{~V}$ and $3 \mathrm{~V}$ (photoluminescence spectra). However, the small emission region at 600-700 $\mathrm{nm}$ (orange-red region) was identified under PL testing. This indicated small intrinsic defects, which was attributed to the presence of small excess of oxygen such as oxygen interstitial.

\section{Competing Interests}

The authors declare that there are no competing interests regarding the publication of this paper.

\section{Acknowledgments}

The authors would like to thank the University of Malaya for funding this research work under Postgraduate Research Fund Scheme (PPP, PG058-2014B), Fundamental Research Grant Scheme (FP008-2015A), Grand Challenge Grant (GC002A-15SBS), COMSTECH-TWAS Joint Research Grants Programme for Young Scientists (14-316 RG/MSN/ AS_C), and Nippon Sheet Glass Foundation for Materials Science and Engineering (IF001-2015).

\section{References}

[1] NASA, NASA, NOAA Analyses Reveal Record-Shattering Global Warm Temperatures in 2015, 2016, http://www.nasa.gov/pressrelease/nasa-noaa-analyses-reveal-record-shattering-globalwarm-temperatures-in-2015.

[2] NASA, Global Climate Change: Vital Signs of the Planet, 2014, http://climate.nasa.gov/.

[3] S. Ameen, M. S. Akhtar, H.-K. Seo, Y. S. Kim, and H. S. Shin, "Influence of Sn doping on $\mathrm{ZnO}$ nanostructures from nanoparticles to spindle shape and their photoelectrochemical properties for dye sensitized solar cells," Chemical Engineering Journal, vol. 187, pp. 351-356, 2012.

[4] M. Abd-Ellah, N. Moghimi, L. Zhang et al., "Effect of electrolyte conductivity on controlled electrochemical synthesis of zinc oxide nanotubes and nanorods," The Journal of Physical Chemistry C, vol. 117, no. 13, pp. 6794-6799, 2013.

[5] S. Ma, R. Li, C. Lv, W. Xu, and X. Gou, "Facile synthesis of $\mathrm{ZnO}$ nanorod arrays and hierarchical nanostructures for photocatalysis and gas sensor applications," Journal of Hazardous Materials, vol. 192, no. 2, pp. 730-740, 2011.

[6] Z. Zheng, Z. S. Lim, Y. Peng, L. You, L. Chen, and J. Wang, "General route to $\mathrm{ZnO}$ nanorod arrays on conducting substrates via galvanic-cell-based approach," Scientific Reports, vol. 3, article 2434, 2013. 
[7] A. Janotti and C. G. Van de Walle, "Fundamentals of zinc oxide as a semiconductor," Reports on Progress in Physics, vol. 72, no. 12, Article ID 126501, 2009.

[8] T. Xu, P. Ji, M. He, and J. Li, "Growth and structure of pure $\mathrm{ZnO}$ micro/nanocombs," Journal of Nanomaterials, vol. 2012, Article ID 797935, 5 pages, 2012.

[9] B. Nikoobakht, X. Wang, A. Herzing, and J. Shi, "Scalable synthesis and device integration of self-registered one-dimensional zinc oxide nanostructures and related materials," Chemical Society Reviews, vol. 42, no. 1, pp. 342-365, 2013.

[10] L. C. Tien, S. J. Pearton, D. P. Norton, and F. Ren, "Synthesis and microstructure of vertically aligned $\mathrm{ZnO}$ nanowires grown by high-pressure-assisted pulsed-laser deposition," Journal of Materials Science, vol. 43, no. 21, pp. 6925-6932, 2008.

[11] A. Kołodziejczak-Radzimska and T. Jesionowski, "Zinc oxidefrom synthesis to application: a review," Materials, vol. 7, no. 4, pp. 2833-2881, 2014.

[12] Z. W. Pan, Z. R. Dai, and Z. L. Wang, "Nanobelts of semiconducting oxides," Science, vol. 291, no. 5510, pp. 1947-1949, 2001.

[13] Y. Huang, J. He, Y. Zhang et al., "Morphology, structures and properties of $\mathrm{ZnO}$ nanobelts fabricated by $\mathrm{Zn}$-powder evaporation without catalyst at lower temperature," Journal of Materials Science, vol. 41, no. 10, pp. 3057-3062, 2006.

[14] J.-J. Wu, S.-C. Liu, C.-T. Wu, K.-H. Chen, and L.-C. Chen, "Heterostructures of $\mathrm{ZnO}-\mathrm{Zn}$ coaxial nanocables and $\mathrm{ZnO}$ nanotubes," Applied Physics Letters, vol. 81, no. 7, pp. 1312-1314, 2002.

[15] W. J. Chen, W. L. Liu, S. H. Hsieh, and T. K. Tsai, "Preparation of nanosized $\mathrm{ZnO}$ using $\alpha$ brass," Applied Surface Science, vol. 253, no. 16, pp. 6749-6753, 2007.

[16] J. Liu, X. Huang, J. Duan, H. Ai, and P. Tu, "A low-temperature synthesis of multiwhisker-based zinc oxide micron crystals," Materials Letters, vol. 59, no. 28, pp. 3710-3714, 2005.

[17] X. Y. Kong, Y. Ding, R. Yang, and Z. L. Wang, "Single-crystal nanorings formed by epitaxial self-coiling of polar nanobelts," Science, vol. 303, no. 5662, pp. 1348-1351, 2004.

[18] R. Wahab, S. G. Ansari, Y.-S. Kim, H.-K. Seo, and H.-S. Shin, "Room temperature synthesis of needle-shaped $\mathrm{ZnO}$ nanorods via sonochemical method," Applied Surface Science, vol. 253, no. 18, pp. 7622-7626, 2007.

[19] D. Banerjee, J. Y. Lao, D. Z. Wang et al., "Large-quantity freestanding ZnO nanowires," Applied Physics Letters, vol. 83, no. 10, pp. 2061-2063, 2003.

[20] Y.-B. Hahn, "Zinc oxide nanostructures and their applications," Korean Journal of Chemical Engineering, vol. 28, no. 9, pp. 17971813, 2011.

[21] T. Frade, M. E. Melo Jorge, and A. Gomes, "One-dimensional $\mathrm{ZnO}$ nanostructured films: effect of oxide nanoparticles," Materials Letters, vol. 82, pp. 13-15, 2012.

[22] W. S. Chiu, P. S. Khiew, M. Cloke et al., "Photocatalytic study of two-dimensional $\mathrm{ZnO}$ nanopellets in the decomposition of methylene blue," Chemical Engineering Journal, vol. 158, no. 2, pp. 345-352, 2010.

[23] M. José-Yacamán, C. Gutierrez-Wing, M. Miki, D.-Q. Yang, K. N. Piyakis, and E. Sacher, "Surface diffusion and coalescence of mobile metal nanoparticles," Journal of Physical Chemistry B, vol. 109, no. 19, pp. 9703-9711, 2005.

[24] V. Polshettiwar, B. Baruwati, and R. S. Varma, "Self-assembly of metal oxides into three-dimensional nanostructures: synthesis and application in catalysis," ACS Nano, vol. 3, no. 3, pp. 728736, 2009.
[25] N. A. Abd Samad, C. W. Lai, and S. B. Abd Hamid, "Easy formation of nanodisk-dendritic $\mathrm{ZnO}$ film via controlled electrodeposition process," Journal of Nanomaterials, vol. 2015, Article ID 563728, 7 pages, 2015.

[26] Q. Xie, Z. Dai, J. Liang, L. Xu, W. Yu, and Y. Qian, "Synthesis of $\mathrm{ZnO}$ three-dimensional architectures and their optical properties," Solid State Communications, vol. 136, no. 5, pp. 304-307, 2005.

[27] J. Liu, X. Huang, Y. Li, K. M. Sulieman, F. Sun, and X. He, "Selective growth and properties of zinc oxide nanostructures," Scripta Materialia, vol. 55, no. 9, pp. 795-798, 2006.

[28] M. Bitenc and Z. C. Orel, "Synthesis and characterization of crystalline hexagonal bipods of zinc oxide," Materials Research Bulletin, vol. 44, no. 2, pp. 381-387, 2009.

[29] G. Lu, X. Wang, J. Liu et al., "One-pot synthesis and gas sensing properties of $\mathrm{ZnO}$ mesoporous architectures," Sensors and Actuators B: Chemical, vol. 184, pp. 85-92, 2013.

[30] W. Schwarzacher, "Electrodeposition: a technology for the future," Electrochemical Society Interface, vol. 15, no. 1, pp. 3233, 2006.

[31] G. Zangari, "Electrodeposition for energy conversion: electrochemistry over matter," Electrochemical Society Interface, vol. 20, no. 2, pp. 31-32, 2011.

[32] I. M. Dharmadasa and J. Haigh, "Strengths and advantages of electrodeposition as a semiconductor growth technique for applications in macroelectronic devices," Journal of the Electrochemical Society, vol. 153, no. 1, pp. G47-G52, 2006.

[33] A. Azam and S. S. Babkair, "Low-temperature growth of well-aligned zinc oxide nanorod arrays on silicon substrate and their photocatalytic application," International Journal of Nanomedicine, vol. 9, no. 1, pp. 2109-2115, 2014.

[34] M. A. Abbasi, Y. Khan, S. Hussain, O. Nur, and M. Willander, "Anions effect on the low temperature growth of $\mathrm{ZnO}$ nanostructures," Vacuum, vol. 86, no. 12, pp. 1998-2001, 2012.

[35] N. H. Alvi, S. M. Usman Ali, S. Hussain, O. Nur, and M. Willander, "Fabrication and comparative optical characterization of $\mathrm{n}-\mathrm{ZnO}$ nanostructures (nanowalls, nanorods, nanoflowers and nanotubes)/p-GaN white-light-emitting diodes," Scripta Materialia, vol. 64, no. 8, pp. 697-700, 2011.

[36] H.-G. Chen, S.-R. Jian, Z.-W. Li, K.-W. Chen, and J.-C. Li, "Epitaxial growth of self-arranged periodic $\mathrm{ZnO}$ nanostructures on sapphire substrates grown by MOCVD," Journal of Alloys and Compounds, vol. 504, no. 1, pp. S368-S371, 2010.

[37] C. Badre, P. Dubot, D. Lincot, T. Pauporte, and M. Turmine, "Effects of nanorod structure and conformation of fatty acid self-assembled layers on superhydrophobicity of zinc oxide surface," Journal of Colloid and Interface Science, vol. 316, no. 2, pp. 233-237, 2007.

[38] X. Y. Zhang, J. Y. Dai, C. H. Lam et al., "Zinc/ZnO core-shell hexagonal nanodisk dendrites and their photoluminescence," Acta Materialia, vol. 55, no. 15, pp. 5039-5044, 2007.

[39] G. J. Exarhos and S. K. Sharma, "Influence of processing variables on the structure and properties of $\mathrm{ZnO}$ films," Thin Solid Films, vol. 270, no. 1-2, pp. 27-32, 1995.

[40] M. Schumm, M. Koerdel, J. F. Morhange et al., "Analysis of the vibrational properties of $\mathrm{Zn}_{1--x} \mathrm{Co}_{x} \mathrm{O}$ by Raman spectroscopy," Journal of Physics: Conference Series, vol. 92, no. 1, Article ID 012149, 2007.

[41] K. Dai, T. Peng, H. Chen, R. Zhang, and Y. Zhang, "Photocatalytic degradation and mineralization of commercial methamidophos in aqueous Titania suspension," Environmental Science and Technology, vol. 42, no. 5, pp. 1505-1510, 2008. 
[42] H.-M. Cheng, H.-C. Hsu, Y.-K. Tseng, L.-J. Lin, and W.-F. Hsieh, "Raman scattering and efficient UV photoluminescence from well-aligned $\mathrm{ZnO}$ nanowires epitaxially grown on $\mathrm{GaN}$ buffer layer," The Journal of Physical Chemistry B, vol. 109, no. 18, pp. 8749-8754, 2005.

[43] Z. Wang, H. Zhang, L. Zhang, J. Yuan, S. Yan, and C. Wang, "Low-temperature synthesis of $\mathrm{ZnO}$ nanoparticles by solidstate pyrolytic reaction," Nanotechnology, vol. 14, no. 1, pp. 11-15, 2003.

[44] Y. Yang, H. Yan, Z. Fu, B. Yang, and J. Zuo, "Correlation between $577 \mathrm{~cm}^{-1}$ Raman scattering and green emission in $\mathrm{ZnO}$ ordered nanostructures," Applied Physics Letters, vol. 88, no. 19, Article ID 191909, 2006.

[45] K. A. Alim, V. A. Fonoberov, and A. A. Balandin, "Origin of the optical phonon frequency shifts in $\mathrm{ZnO}$ quantum dots," Applied Physics Letters, vol. 86, no. 5, Article ID 053103, 3 pages, 2005.

[46] C. Roy, S. Byrne, E. McGlynn et al., "Correlation of Raman and X-ray diffraction measurements of annealed pulsed laser deposited $\mathrm{ZnO}$ thin films," Thin Solid Films, vol. 436, no. 2, pp. 273-276, 2003.

[47] Z. L. Wang, "Zinc oxide nanostructures: growth, properties and applications," Journal of Physics: Condensed Matter, vol. 16, no. 25, pp. R829-R858, 2004.

[48] C. Chandrinou, N. Boukos, C. Stogios, and A. Travlos, "PL study of oxygen defect formation in $\mathrm{ZnO}$ nanorods," Microelectronics Journal, vol. 40, no. 2, pp. 296-298, 2009.

[49] X.-Y. Shen, Y.-C. Zhai, and Y.-H. Zhang, "Preparation and characterization of ultrafine zinc oxide powder by hydrothermal method," Transactions of Nonferrous Metals Society of China, vol. 20, no. 1, pp. s236-s239, 2010.

[50] A. B. Djurišić, Y. H. Leung, K. H. Tam et al., "Defect emissions in $\mathrm{ZnO}$ nanostructures," Nanotechnology, vol. 18, no. 9, Article ID 095702, 2007.

[51] N. H. Alvi, Luminescence Properties of ZnO Nanostructures and Their Implementation as White Light Emitting Diodes (LEDs), Linköping University, 2011.

[52] F. A. Kröger and H. J. Vink, "The origin of the fluorescence in self-activated $\mathrm{ZnS}, \mathrm{CdS}$, and $\mathrm{ZnO}$," The Journal of Chemical Physics, vol. 22, no. 2, pp. 250-252, 1954.

[53] S. A. Studenikin, N. Golego, and M. Cocivera, "Fabrication of green and orange photoluminescent, undoped $\mathrm{ZnO}$ films using spray pyrolysis," Journal of Applied Physics, vol. 84, no. 4, pp. 2287-2294, 1998.

[54] S. Yamauchi, Y. Goto, and T. Hariu, "Photoluminescence studies of undoped and nitrogen-doped $\mathrm{ZnO}$ layers grown by plasmaassisted epitaxy," Journal of Crystal Growth, vol. 260, no. 1-2, pp. $1-6,2004$.

[55] A. Janotti and C. G. Van de Walle, "Native point defects in ZnO," Physical Review B, vol. 76, no. 16, Article ID 165202, 2007.

[56] H. Zhou, H. Alves, D. M. Hofmann et al., "Behind the weak excitonic emission of $\mathrm{ZnO}$ quantum dots: $\mathrm{ZnO} / \mathrm{Zn}(\mathrm{OH})_{2}$ coreshell structure," Applied Physics Letters, vol. 80, no. 2, pp. 210$212,2002$.

[57] S. Licht, B. Wang, S. Mukerji, T. Soga, M. Umeno, and H. Tributsch, "Over 18\% solar energy conversion to generation of hydrogen fuel; theory and experiment for efficient solar water splitting," International Journal of Hydrogen Energy, vol. 26, no. 7, pp. 653-659, 2001.

[58] G. A. Crawford and N. Chawla, "Porous hierarchical $\mathrm{TiO}_{2}$ nanostructures: processing and microstructure relationships," Acta Materialia, vol. 57, no. 3, pp. 854-867, 2009.
[59] C. W. Lai and S. Sreekantan, "Effect of applied potential on the formation of self-organized $\mathrm{TiO}_{2}$ nanotube arrays and its photoelectrochemical response," Journal of Nanomaterials, vol. 2011, Article ID 142463, 7 pages, 2011. 

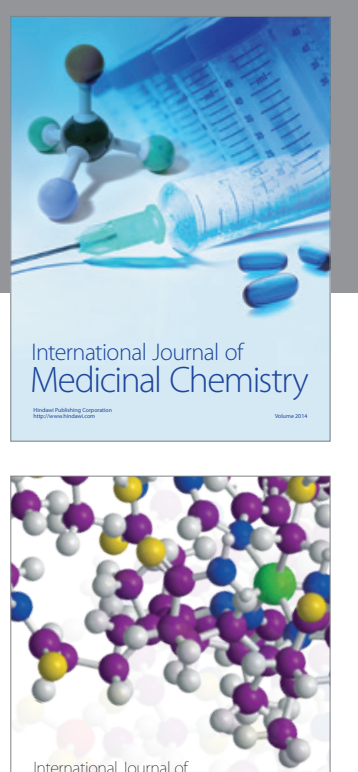

Carbohydrate Chemistry

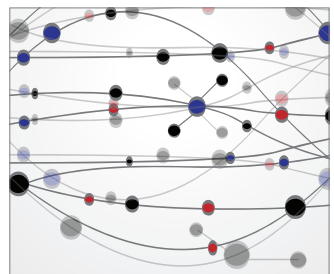

The Scientific World Journal
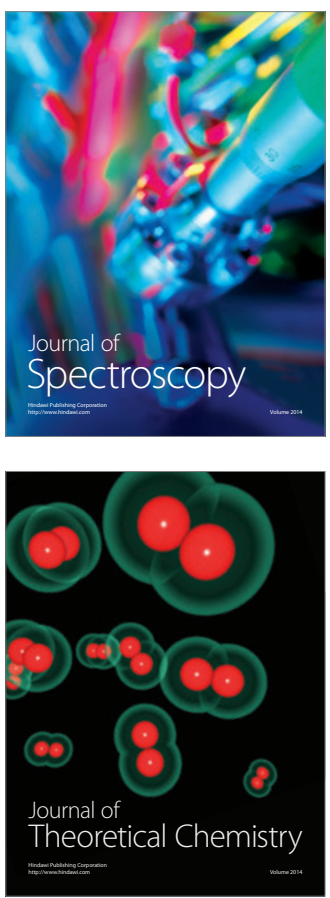
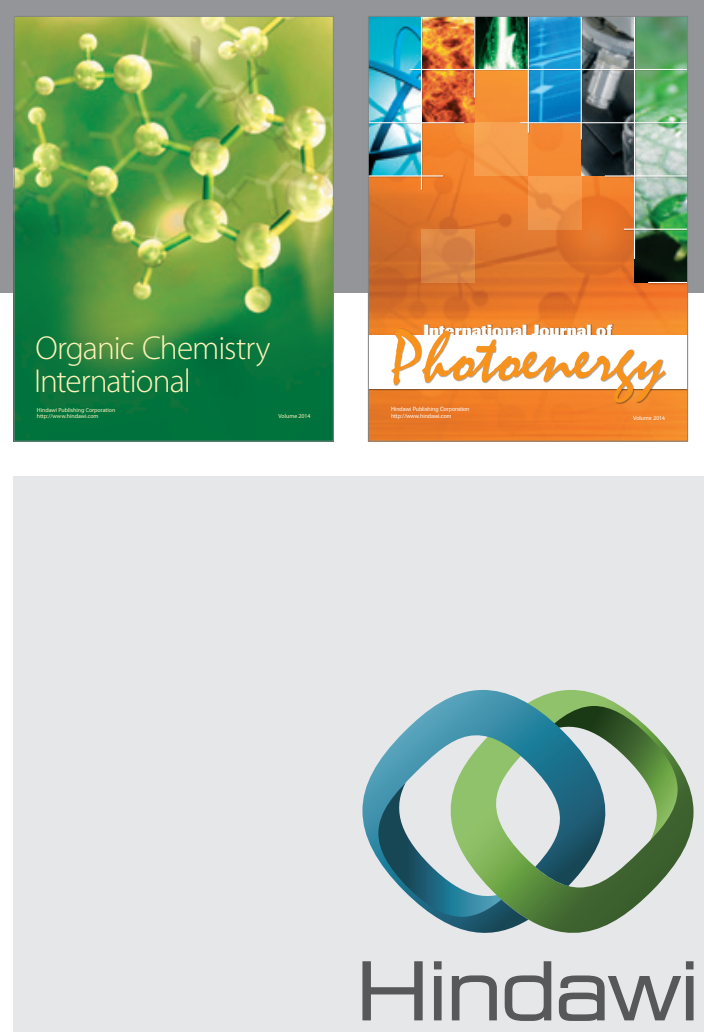

Submit your manuscripts at

http://www.hindawi.com

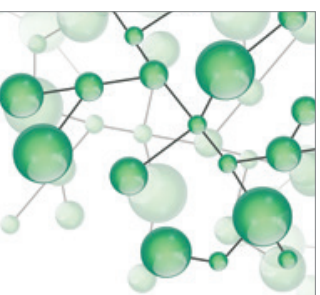

International Journal of

Inorganic Chemistry

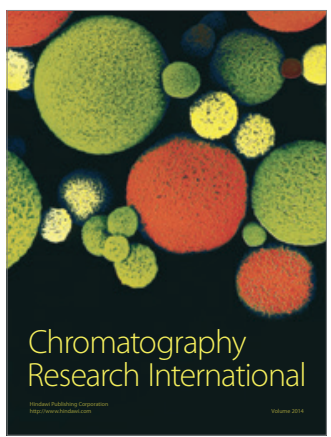

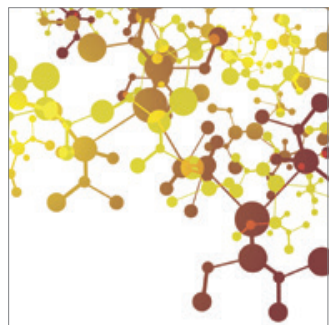

Applied Chemistry
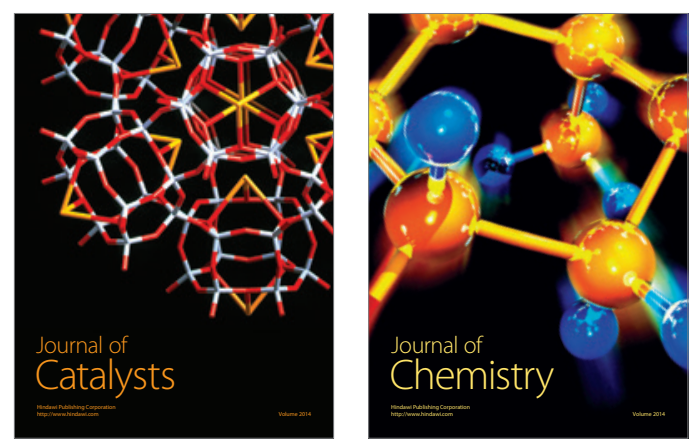
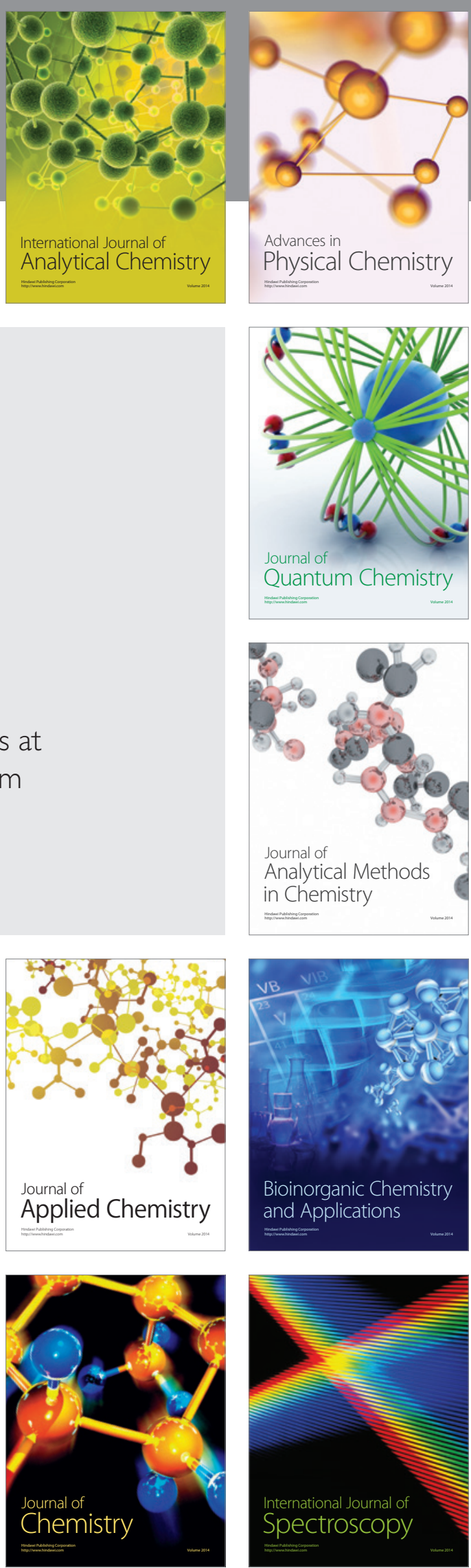